The 3rd International Conference on Biological Science 2013

(The 3rd ICBS-2013)

\title{
POTENCY OF BRASSICACEAE EXTRACTS AS AN APOPTOSIS ENCHANCER IN BLOOD CELLS MICE EXPOSED TO LEAD ACETATE
}

\author{
Supartini Syarif ${ }^{1 *}$, Madihah $^{1}$ \\ 1 Jurusan Biologi, FMIPA UNPAD \\ Jl. Raya Bandung-Sumedang KM. 21 Jatinangor 45363 \\ email: supartini_syarif@yahoo.co.id
}

\begin{abstract}
Lead $(\mathrm{Pb})$ is an environmental pollutant that is widely used in various industries. It has genotoxic effect that can trigger cancer formation (carcinogenic). The member of Brassicaceae family (white headed cabbage, pak choi, and Chinese cabbage) is known to have glucosinolates, isothiocyanates, phenethilisothiocyanates, and alyl isothiocyanates which are anticarcinogenic. The aim of this study was to examine the potential of Brassicaceae extracts to enhance apoptosis in mouse blood cell exposed to lead acetate. The research method was descriptive with five treatments and four replications. Mice were pretreated with white headed cabbage, pak choi, and Chinese cabbage extracts by cumulative dose $156 \mathrm{mg} / \mathrm{kg}$ bw for 13 days prior to exposure of lead acetate by cumulative dose $150 \mathrm{mg} / \mathrm{kg} \mathrm{bw}$. All treatment was given orally. Blood samples were taken on the thirteenth day from the tail venous vessel. Furthermore, the DNA isolation and electrophoresis were done to examine DNA fragmentation. The result showed that the white headed cabbage extract enhanced the formation of a $200 \mathrm{bp}$ DNA ladder pattern that is characteristic of apoptosis in the mice blood cells due to lead acetate exposures.
\end{abstract}

Key words: apoptosis, lead acetate, white headed cabbage, pak choi, Chinese cabbage

\section{INTRODUCTION}

Heavy metals like $\mathrm{Pb}, \mathrm{Cd}, \mathrm{Cu}, \mathrm{Fe}$, and $\mathrm{Hg}$, contribute significantly to the growing pollution problem. Lead $(\mathrm{Pb})$ is used in the manufacture of batteries, metal products, paints and ceramic glazes; the large source of lead in the atmosphere has been from combustion. Lead is absorbed mainly by ingestion and inhalation. Internal and external factors, including environmental pollutants induced various kind of genetic damage. Lead is genotoxic itself or enhances the effect of other DNA-damaging agents that can trigger cancer formation.

Prevention of the cancer and other mutation related disease can be carry on both by avoiding exposure to carcinogen and by favoring the intake of protective factors which fortify physiological defense mechanisms (Ishaq et al., 2003). In recent years, there is increasing awareness that certain naturally occurring substance in plants provide protection against environmental carcinogen or mutagens. The Brassicaceae (Cruciferae) family has chemopreventive potential (anti carcinogenic). Anticarcinogenic effect of these vegetables, particularly due to their content in glucosinolate, is hydrolyzed by specific thioglucosidases called myrosinases to produces isothiocyanates, nitriles, and thiocyanates with different biological activity (Rubattzy \& Yamaguchi, 1994; Talalay \& Fahey, 2001; Miyazawa et al., 2003; Weil et al. 2004; Mandelova \& Totusek, 2007). Isothyosianate (ITC) may also be able to suppress tumor cell growth, and it has been recognized that isothiocyanates can inhibit cell cycle progression and trigger apoptosis in tumor cells (Tseng et al., 2004). The most characterized ITC is sulforaphane, it has ability to simultaneously modulate multiple cellular target involved in cancer development, including: (1) DNA protection by modulating metabolizing

ISSN 2413-0877 (c) 2015 The Authors.

Published by KnowledgeE Publishing Services This is an open access article under the CC BY-NC-ND license (http://creativecommons.org/licenses/by-nc-nd/4.0)

Selection and Peer-review under responsibility of the 3rd ICBS-2013

Doi http://dx.doi.org/10.18502/kls.v2i1.132 
enzyme and blocking the action of mutagens; (2) inhibition of cell proliferation and induction of apoptosis; (3) inhibition of neoangiogenesis (Fimognari \& Hrelia, 2007). This study was conducted to examine the anticarcinogenic potential of Brassicaceae vege-tables (Brassica rapa L. cv. Group Pak Choi, Brassica Oleracea L. cv. Group White Headed Cabbage, and Brassica rapa L. cv. Group Chinese Cabbage) extracts to enhance apoptosis in mice blood cell that exposed to lead acetate.

\section{MATERIALS AND METHODS}

\section{Animal}

Animal experiments were 8-10 week old Swiss Webster male mice weighing 20-25 g obtained from Structure and Developmental Animal Laboratory, Faculty of Mathematics and Natural Sciences, Padjadjaran University. The animals were maintained at $\pm 25^{\circ} \mathrm{C}$ with 12 hr light and dark cycle. Animal were fed with commercial standard mouse diet (CP 551) and water ad libitum.

\section{Chemicals and substances}

Lead Acetate (Merck), Carboxy Methyl Cellulose (Merck) as emulsifier, 95\% diethyl ether, extracts from Brassicaceae vegetables (Brassica rapa L. cv. Group Pak Choi, Brassica oleracea L. cv. Group White Headed Cabbage, and Brassica rapa L. cv. Group Chinese Cabbage), Apoptotic DNA Ladder Kit (Roche; Cat. No. 11835246 001).) and 100 bp-DNA marker (Roche; Cat. No. $11449460001^{*}$ ).

\section{Extraction}

The Brassicaceae vegetables were cut and blended. Ethanol extract was prepared by extraction of leaves in $95 \%$ ethanol in a soxhalet apparatus for $72 \mathrm{~h}$. The liquid extract was then cooled and concentrated by rotary evaporation at $40^{\circ} \mathrm{C}$ to get pasta form-extract.

\section{Treatment Procedure}

Twenty of 8-10 weeks old mice weighing 20-25 g were allowed without food for $4 \mathrm{~h}$ before treatment. There were five experimental groups and each group consisted of four male mice. Group I of negative control was administered with CMC $0.5 \%(\mathrm{KN})$, group II of positive control was administered with $150 \mathrm{mg} / \mathrm{kg}$ bw lead acetate (KP) (Aly, 2001). Groups III, IV, and V were pretreated with $156 \mathrm{mg} / \mathrm{kg}$ bw of pak choi extract (PK), $156 \mathrm{mg} / \mathrm{kg}$ bw white headed cabbage extract (KC) and $156 \mathrm{mg} / \mathrm{kg}$ bw Chinese cabbage extract (PT) respectively for $7(1,3,5,7,9,11$, and 13) consecutive days $(22.22 \mathrm{mg} / \mathrm{kg} \mathrm{bw} /$ day) prior to treatment with lead acetate dose of $150 \mathrm{mg} / \mathrm{kg}$ bw on day 5,9 and 13 (50 mg/kb bw/day). All treatment was given orally.

\section{DNA Isolation and Electrophoresis}

Formation of DNA fragments in apoptotic cell death in each treatment group was detected from the blood sample. An hour after last treatment (day 13), blood sample was taken from the tail and DNA was isolate by the method of Roche using Apoptotic DNA Ladder Kit. As an apoptotic positive control was U937 cell (Roche). DNA concentration was measured 
by biophotometer at wavelength of 230,260 and $280 \mathrm{~nm}$. DNA was then electrophoreses on a $1 \%$ agarose gel using 100 bp DNA marker (Roche). Electrophoresis was using 2 ug of DNA sample and carried out at $75 \mathrm{~V}$ for $1.5 \mathrm{hours}$. Gel was stain by ethidium bromide solution for $10 \mathrm{~min}$ and distilled water for $5 \mathrm{~min}$. DNA bands were visualized and documented by UV transilluminator. Formation of a 200 bp DNA ladder pattern was indicating the occurrence of apoptosis in the mouse blood cell. The data were descriptively analyzed.

\section{RESULT AND DISCUSSION}

Electrophoregram of mice blood cell DNA from all treatments was shown in Figure 1. The results of DNA electrophoresis that isolated from the blood of mice showed that the treatment of lead acetate dose of $150 \mathrm{mg} / \mathrm{kb}$ bw caused DNA fragmentation (column 1, Figure 1). By using a same amount of DNA sample, thicker band was shown from sample was treated with white headed cabbage extract. This result indicated that white headed cabbage may enhanced apoptosis (column 14, Figure 1). However, the mechanism of apoptosis cell death induced by lead and isothiocyanates compounds contained in Brassicaceae vegetables occurs through different signal transduction pathways.

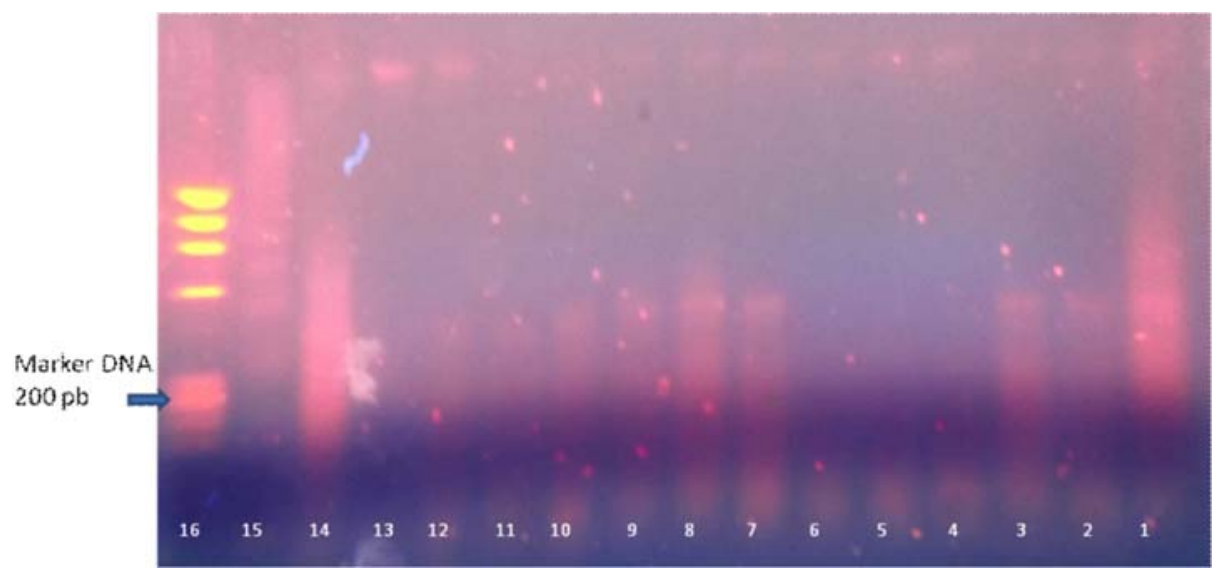

Figure 1. Electrophoregram that showing DNA ladder pattern from apoptotic mice blood cells.

$\begin{array}{lllll}\text { Ket.: } & \text { 1. KP1 } & \text { 5. KP3 } & \text { 9. PT1 } & \text { 13. KC2 } \\ & \text { 2. KP2 } & \text { 6. PK1 } & \text { 10. PT2 } & \text { 14. KC3 } \\ & \text { 3. KN1 } & \text { 7. PK2 } & \text { 11. PT3 } & \text { 15. sel U937 } \\ & \text { 4. KN2 } & \text { 8. PK3 } & \text { 12. KC1 } & \text { 16. DNA Marker }\end{array}$

The regulations of apoptosis are complex and two important pathways are involved. Apoptosis is regulated by $\mathrm{Bcl}-2$ protein family that consists of anti-apoptotic proteins such as Bcl-2, Bcl-xl, Bcl-w, and pro-apoptotic proteins such as Bax, Bak, and Bad. In extrinsic apoptosis, external signals interact with death receptors, which in turn activate caspase-8 subsequent to the activation of caspase- 7 and caspase- 3 as an effectors process of apoptosis, such as caused by isothiocyanate compounds. In intrinsic apoptosis, the loss of mitochondrial transmembrane potential caused by accumulation of $\mathrm{Ca}^{2+}$ ion, and together with Bax protein may initiate cytochrome $c$ release, which binds to apoptotic activating factor-1 (Apaf-1). Oligomer of Apaf-I then binds to procaspase-9 form apoptosom (complex activation of Caspase-9). Caspase-9 subsequently activates caspase-3 as an effector apoptotic process, such that caused by lead. In multiple cell types, activated caspase-3 will 
result in certain apoptotic hallmarks, such as chromatin condensation and DNA fragmentation (Xu et al., 2006).

Lead toxicity is thought to relate to its affinity for some protein and can mimic $\mathrm{Ca}^{2+}$ ion action. Lead interact with enzyme functional groups and high-affinity metal-binding proteins, such as $\mathrm{Pb}$-binding proteins and metallothioneins, can mediate this $\mathrm{Pb}$-enzyme interaction. Lead exposure can induce DNA damage that leads to increased expression of protein Bax and decreased the expression of $\mathrm{Bcl}-2$ protein. DNA damage activates p53 which in turn triggers Bax gene expression resulting in an imbalance ratio between $\mathrm{Bax}$ to $\mathrm{Bcl}-2$ and interfere with mitochondrial function. This will activate caspase-3 and causes the cell to undergo apoptosis (Xu et al., 2006).

According Barillari et al. (2007), vegetables of the Brassicaceae family contain glucosinolates compound which can hydrolyze into isothiocyanates in the digestive tract. Isothiocyanates compound contained in Brassicaceae vegetables are function as anti oxidants, anti cancer and anti mutagen, that can induce apoptosis (Nakamura et al., 2001; Barillari et al., 2007). Isothiocyanates can be converted into glutathione conjugates with the aid of the enzyme glutathione S-transferase (GSTs). Glutathione conjugate, S-(NPhenethylthiocarbamoil) glutathione, will be taken out of the cell and metabolized into mercapturic acids, Ná-acetyl-S-(N'-Phenethylthiocarbamoil) cysteine. This compound was able to induce apoptosis in cancer cells and inhibit cancer growth by activating enzymes that play a role in the detoxification process such as quinone reductase and epoxide hydrolase (Xu \& Thornalley, 2001).

One class of isothiocyanate compounds is sulforaphane. The in vivo and in vitro study results suggest that sulforaphane can modulate early stages of cancer formation (initiation stage), such as apoptosis, cell proliferation, and angiogenesis (Fimognari \& Hrelia, 2006). Inhibition of genetic damage by isothiocyanate compounds or suspected sulforaphane was an early mechanism to prevent the onset of cancer. Inhibitory mechanism occurs through the inhibition or competition with enzymes that metabolize xenobiotic (phase I and II detoxification enzymes), scavenge free radicals, and protect the nucleophilic sites on DNA, namely through the formation of complex with mutagens or modulate cell repair, cell cycle, or cell death via apoptosis.

Thus, pretreatment with Brassicaceae extract dose of $156 \mathrm{mg} / \mathrm{kg}$ bw prior to lead acetate exposure dose of $150 \mathrm{mg} / \mathrm{kg}$ bw can enhance the occurrence of apoptosis in the mice blood cell, mainly the White headed cabbage. The mechanism of apoptosis occurs through the binding of mutagens, in this case lead ions, and formed a complex between lead ionisothiocyanate compounds which can inhibit DNA damage, and prevent formation of cancer.

\section{REFERENCES}

Aly, F.W. 2001. Potential Mutagenic Effect of Lead Acetate in mouse Bone Marrow and culture Mouse Spleen Cells. http://www.jst.go.jp/article/char/en.

Barillari, J., R. Iori, M. Broccoli, L. Pozzetti, D. Canistro, A. Sapone, B. Bonamassa, G.L. Biagi, and M. Paolini. 2007. Glucoraphasatin and glucoraphenin, a redox pair of glucosinolates of brassicaceae, differently affect metabolizing enzymes in rats. J Agric Food Chem. 55(14):5505-11. 
Fimognari, C., and P. Hrelia. 2006. Sulforaphane as a promising molecule for fighting Cancer. http://www.Scientiesdirect.com/science?_ob=Mlmg.

Ishaq, G.M., M.Y. Shah, S.A. Tanki 2003. Cancer Chemoprevention Through Natural Antimutagenic Agents .JK-Practioner 10(2):101-106

Mandelova, L., and J. Totusek 2007. Broccoli Juice Treated by high Pressure: Chemoprotective Effects of Sulforaphane and Indole-3 carbinol. High Pressure Research (27): $151-156$

Miyazawa, M., T. Nishiguchi and C. Yamafuji 2003. Volatile components of leaves of Brassica rapa L.var. pervidis Bailey. Flavour and Fragrance J. (20):158- 160

Nakamura, Y., T. Iwahasi; T. Tanaka; J. Koutani, T. Omatsuo, S. Okamoto, K. Sato; K. Ohtsuki. 2001. 4-(Methylthio)-3-butenyl isothiocyanate, a principal antimutagen in daikon (Raphanus sativus, Japanese white radish). Journal Agric Food Chem 49(12): 57555760.

Rubatzky, V.E., dan M. Yamaguchi. 1998. Sayuran Dunia 2. Prinsip, Produksi dan Gizi. Penerbit ITB Bandung.

Talalay, P., and J.W. Fahey. 2001. Phytochemicals from Cruciferous Plants Protect against Cancer by Modulating Carcinogen Metabolism. The Journal of Nutrition (131):30273033

Tseng, T., E.A. Ramsey, and M.E. Morris. 2004. Dietary organic isothiocyanates are cytotoxic in human breast cancer MCF-\& and mammary epithelial MCF-12A cell lines. Exp. Biol. Med. 229:835-842.

Weil, M.J., Y. Zhang, M.G. Nair. 2004. Colon Cancer Proliferating Desulfosinigrin in Wasabi (Wasabia japonica). Nutrition and Cancer (48):207-213

$\mathrm{Xu}, \mathrm{K}$. and P.J. Thornalley 2001. Studi on the mechanism of the inhibition of human leukemia cell growth by dietary isothiocyanates and their cysteine adduct. In vitro. Biochem.Pharmacol. $60: 221-231$.

Xu, J., L.D. Ji., and L.H. Xu. 2006. Lead-induced apoptosis in PC 12 cells: Involvement of p53, Bcl-2 family and caspase-3. Toxicology Letters 166: 160-167. 